\title{
TTR
}

Traduction, terminologie, re?daction

\section{Theories of Translation}

\section{Eugene A. Nida}

Volume 4, numéro 1, 1st semester 1991

Languages and Cultures in Translation Theories

URI : https://id.erudit.org/iderudit/037079ar

DOI : https://doi.org/10.7202/037079ar

Aller au sommaire du numéro

\section{Éditeur(s)}

Association canadienne de traductologie

\section{ISSN}

0835-8443 (imprimé)

1708-2188 (numérique)

Découvrir la revue

\section{Citer cet article}

Nida, E. A. (1991). Theories of Translation. TTR, 4(1), 19-32.

https://doi.org/10.7202/037079ar d'utilisation que vous pouvez consulter en ligne.

https://apropos.erudit.org/fr/usagers/politique-dutilisation/ 


\title{
Theories of Translation
}

\author{
Eugene A. Nida
}

Discussions about theories of translation are too often concemed with distinctions between literary and nonliterary texts, between prose and poetry, or between technical articles on physics and run-of-the-mill commercial correspondence. But in order to understand the nature of translation, the focus should not be on different types of discourse but on the processes and procedures involved in any and all kinds of interlingual communication (Bell, 1987). Furthermore, a theory of interlingual communication should not be restricted to discussions between translating and interpreting (whether consecutive or simultaneous), since interpreting differs from translating primarily because of the pressures of time and exigencies of the setting.

Some professional translators take considerable pride in denying that they have any theory of translation - they just translate. In reality, however, all persons engaged in the complex task of translating possess some type of underlying or covert theory, even though it may be still very embryonic and described only as just being "faithful to what the author was trying to say."

Instead of no theories of translation, there are a multiplicity of such theories, even though they are seldomly stated in terms of a full-blown theory of why, when, and how to translate. One of the reasons for so many different views about translating is that interlingual communication has been going on since the dawn of human history. As early as the third millenium BC, bilingual lists of words - evidently for the use of translators - were being made in Mesopotamia, and today translating and interpreting are going on in 
more than a thousand languages - in fact, wherever there are bilinguals.

One of the paradoxes of interlingual communication is that it is both amazingly complex (regarded by I.A. Richards (1953) as "probably the most complex type of event yet produced in the evolution of the cosmos") and also completely natural (Harris and Sherwood, 1978). Interpreting is often done by children with amazingly fine results, especially before they have gone to school and have learned something about nouns, verbs, and adjectives.

One reason for the great variety of translation theories and subtheories is the fact that the processes of translating can be viewed from so many different perspectives: stylistics, author's intent, diversity of languages, differences of corresponding cultures, problems of interpersonal communication, changes in literary fashion, distinct kinds of content (e.g. mathematical theory and lyric poetry), and the circumstances in which translations are to be used, e.g. read in the tranquil setting of one's own living room, acted on the theatre stage, or blared from a loudspeaker to a restless mob.

The wide range of theories and the great diversity of problems in translation have been treated by a number of persons interested in translation theory and practice, e.g. Güttinger (1963), Vázquez Ayora (1977), and Wilss (1988).

A theory should be a coherent and integrated set of propositions used as principles for explaining a class of phenomena. But a fully satisfactory theory of translating should be more than a list of rules-of-thumb by which translators have generally succeeded in reproducing reasonably adequate renderings of source texts. A satisfactory theory should help in the recognition of elements which have not been recognized before, as in the case of black holes in astrophysics. A theory should also provide a measure of predictability about the degree of success to be expected from the use of certain principles, given the particular expectations of an audience, the nature of the content, the amount of information carried by the form of the discourse, and the circumstances of use.

Despite a number of important treatments of the basic principles and procedures of translation, no full-scale theory of translation now exists. In fact, it is anomalous to speak of "theories of translation," since all that has been accomplished thus far are important series of insightful perspectives on this complex undertaking. 
The basic reason for this lack of adequate theoretical treatments is that translating is essentially a technology which is dependent upon a number of disciplines: linguistics, cultural anthropology, psychology, communication theory, and neurophysiology. We really know so little about what makes translators tick. But tick they must - and increasingly so in a shrinking multilingual world.

Instead of speaking of theories of translation, we should perhaps speak more about various approaches to the task of translating, different orientations which provide helpful insight, and diverse ways of talking about how a message can be transferred from one language to another. The different ways in which people go about the task of interlingual communication can perhaps be best described in terms of different perspectives: (1) the source text, including its production, transmission, and history of interpretation, (2) the languages involved in restructuring the source-language message into the receptor (or target) language, (3) the communication events which constitute the setting of the source message and the translated text, and (4) the variety of codes involved in the respective communication events. These four different perspectives could be regarded as essentially philological, linguistic, communicative, and sociosemiotic.

These four major perspectives on the problems of interlingual communication should not, however, be regarded as competitive or antagonistic, but as complementary and supplementary. They do not invalidate one another but result in a broader understanding of the nature of translating. They do, nevertheless, reflect an interesting historical development as the focus of attention has shifted from emphasis on the starting point, namely, the source text, to the manner in which a text is understood by those who receive and interpret it. Such a development is quite natural in view of the fact that all communication is goal oriented and moves from the source's intention to the receptor's interpretation.

\section{The philological perspective}

The philological perspective on translation in the Western World goes back ultimately to some of the seminal observations by such persons as Cicero, Horace, Augustine, and Jerome, whose principal concerns were the correct rendering of Greek texts into Latin. In the seventeenth and eighteenth centuries in Europe the philological orientation in translating focused on the issue of "faithfulness," usually bound closely to the history of interpretation of the text, something which 
was especially crucial in the case of Bible translations. For the most part, arguments about the adequacy of translations dealt with the degree of freedom which could or should be allowed, and scholars discussed heatedly whether a translator should bring the reader to the text or bring the text to the reader. Some of the most important early contributions to the philological aspects of translation were made by Luther (1530), Étienne Dolet (1540), Cowley (1656), Dryden (1680), and Pope (1715), but Luther's influence was probably the greatest in view of his having directly and indirectly influenced so many Bible translations first in Western Europe and later in other parts of the world.

This philological perspective is still very much alive, as witnessed by the important contributions of such persons as Cary and Jumpelt (1963), George Steiner (1975), and John Felstiner (1980). Felstiner's book on Translating Neruda is a particularly valuable contribution to the problem of translating lyric poetry. And the numerous articles in Translation Review, published by the University of Texas at Dallas on behalf of the American Literary Translators Association, represent very well this philological perspective.

It is amazing, however, that avowedly philological approaches to translating can result in such radically different results. Those who set their priorities on preserving the literary form produce the kinds of translations which one finds in the text of 2 Corinthians 10.14-16 in the New American Standard Version of the Bible:

For we are not overextending ourselves, as if we did not reach to you, for we were the first to come even as far as you in the gospel of Christ; not boasting beyond our measure, that is, in other men's labors, but with the hope that as your faith grows, we shall be, within our sphere, enlarged even more by you, so as to preach the gospel even to the regions beyond you, and not to boast in what has been accomplished in the sphere of another.

The Greek of this passage is not stylistically bad, but this English butchering of it is hacking at its worst.

Many translators have, however, succeeded brilliantly in combining sensitivity to style with faithfulness to content, perhaps represented most strikingly in the rendering of the plays of Aristophanes by Benjamin B. Rogers in the Loeb series (1924). The Clouds is an especially difficult text to translate adequately, since it 
combines sublime lyrical passages, sharp barbs against philosophy, satirical treatment of Greek education, and ribald humor, which must have kept the crowds roaring with laughter. Rogers makes the text come alive with frequent shifts in meter to match the mood, clever plays on the meanings of words, and particularly adroit handling of dialogue, even to the point of toning down the scatological comments to match the Victorian tastes of his readers.

A number of the essential features and limitations of the philological perspective on translating literary works are helpfully described and discussed by Paz (1971) and by Mounin (1963). Octavio Paz has the special gift of being able to discuss issues of literary translation with the touch of a literary artist, which indeed he is. And Georges Mounin has a way of delineating diverse opinions and judgments so as perform an elegant balancing act.

Those who have followed primarily a philological orientation toward translating have increasingly recognized that other factors must be given greater attention. In the volume On Translation, edited by Brower (1959), and in the volume Translation: Literary, Linguistic, and Philosophical Perspectives, edited by Frawley (1984), these broader factors of linguistic and cultural matters are introduced and point the way to a more satisfactory approach to some of the crucial problems confronted by translators.

\section{The linguistic perspective}

Since translating always involves at least two different languages, it was inevitable that a number of persons studying the issues of translation would focus upon the distinctive features of the source and receptor languages. Important studies of diverse linguistic structures by such persons as Sapir, Bloomfield, Trubetskoy, and Jakobson laid the foundation for a systematic study of the functions of language. Then the analysis of languages outside of the Semitic and IndoEuropean families by linguist-anthropologists provided the creative stimulus for seeing interlingual relations in new and creative ways. Chomsky $(1965,1972)$ and his colleagues added a dynamic dimension to language structure through the use of transformations. All this led to the publication of a number of books on translating which have focused primary attention on the correspondences in language structures. Some of the most important of these books were by Vinay and Darbelnet (1958), Nida (1964), Catford (1965), Tatilon (1986), Larson (1984) and Malone (1988). 
Except for Malone's volume, most books dealing with the linguistic aspects of translating have been essentially aimed at meaningful relations rather than purely formal ones. This is particularly true of the approach of Nida and of Larson. But Malone's volume employs a transformational orientation for a number of formal and semantic processes, including equation, substitution, divergence, convergence, amplification, reduction, diffusion, and condensation. This focus on processes is very productive, but greater attention needs to be paid to the pragmatic features of the original message and to the circumstances regarding the use of a translation.

Developments in transformational-generative grammar, with its Boolean rewrite rules and seemingly precise formulas for embedding, gave machine translating a great methodological boost, but this was not adequate to fulfill the expectations aroused through early promotion by computer enthusiasts. The limited success of machine translating, since it requires so much preediting and postediting, has resulted in a shift of focus from purely linguistic methods to Artificial Intelligence as a possible source of fresh insights. But even with highly sophisticated techniques the resulting translations often sound very unnatural (Somers et al., 1988).

Some important indirect contributions to a linguistic approach to translating have been made by a number of philosophers interested in linguistic analysis as a way of bringing philosophy down from the clouds of truth, beauty, and goodness to the realism of talking about the language of philosophical discussion. Some of the most influential of these philosophers have been Wittgenstein (1953), Cassirer (1953), Grice (1968), Quine (1953, 1959), and Riccur (1969). Many of their insights have been effectively discussed from the linguistic viewpoint by Wells (1954), Antal (1963), Leech (1970), and Moravcsik (1972). These developments provided an important stimulus for developing a less naive approach to epistemology in translation theory. It also encouraged greater interest in the ordinary uses of language in dialogue and helped to undermine false confidence in the reliability of natural language.

A number of psychological insights about translating have been contributed by Ladmiral (1972), who has treated a variety of psychological factors which influence the ways in which linguistic and cultural elements in communication are processed by the mind. And Lambert (1978) has distinguished two different types of bilingualism based on a speaker's degree of integration of the 
respective language codes. This should prove very useful in understanding certain marked differences in the manner in which translators and interpreters perform.

\section{The communicative perspective}

The volume From One Language to Another (de Waard and Nida, 1986) reflects the importance of a number of basic elements in communication theory, namely, source, message, receptor, feedback, noise, setting, and medium. It also treats the processes of encoding and decoding of the original communication and compares these with the more complex series in the translation process.

Linguists working in the field of sociolinguistics, e.g. Labov (1972), Hymes (1974), and Gumperz (1982), have made particularly important contributions to understanding principles of translating which focus upon various processes in communication. This relation between sociolinguistics and translation is a very natural one, since sociolinguists deal primarily with language as it is used by society in communicating. The different ways in which societies employ language in interpersonal relations are crucial for anyone concerned with translating.

Any approach to translating based on communication theory must give considerable attention to the paralinguistic and extralinguistic features of oral and written messages. Such features as tone of voice, loudness, peculiarities of enunciation, gestures, stance, and eye contact are obviously important in oral communication, but many people fail to realize that analogous factors are also present in written communication, e.g. style of type, format, quality of paper, and type of binding.

For effective impact and appeal, form cannot be separated from content, since form itself carries so much meaning, although in Suzanne Langer's sense of "presentational" rather than "discoursive" truth (1951). This joining of form and content has inevitably led to more serious attention being given to the major functions of language, e.g. informative, expressive, cognitive, imperative, performative, emotive, and interpersonal, including the recognition that the information function is much less prominent than has been traditionally thought. In fact, information probably accounts for less that twenty percent of what goes on in the use of language. 
This emphasis upon the functions of language has also served to emphasize the importance of discourse structures, also spoken of as "rhetoric" and "poetics," in which important help for translators has come through contributions by Jakobson (1960), Grimes (1972), and Traugott and Pratt (1980). This focus on discourse structures means that any judgment about the validity of a translation must be judged in terms of the extent to which the corresponding source and receptor texts adequately fulfill their respective functions.

A minimal requirement for adequacy of a translation would be that the readers would be able to comprehend and appreciate how the original readers of the text understood and possibly responded to it. A maximal requirement for translational adequacy would mean that the readers of the translation would respond to the text both emotively and cognitively in a manner essentially similar to the ways in which the original readers responded. The minimal requirement would apply to texts which are so separated by cultural and linguistic differences as to make equivalent responses practically impossible, e.g. translations into English of West African healing incantations. A maximal requirement would apply to the translation of some of Heinrich Heine's poems into English.

Such requirements of equivalence point to the possibilities and limitations of translating various text types having diverse functions. Mounin (1963) treats this same issue as a matter of "translatability," and Reiss (1972) has discussed the communicative aspects of translation by calling attention to the issue of functional equivalence.

\section{The sociosemiotic perspective}

The central focus in a sociosemiotic perspective on translation is the multiplicity of codes involved in any act of verbal communication. Words never occur without some added paralinguistic or extralinguistic features. And when people listen to a speaker, they not only take in the verbal message, but on the basis of background information and various extralinguistic codes, they make judgments about a speaker's sincerity, commitment to truth, breadth of learning, specialized knowledge, ethnic background, concern for other people, and personal attractiveness. In fact, the impact of the verbal message is largely dependent upon judgments based on these extralinguistic codes. Most people are completely unaware of such codes, but they are crucial for what people call their "gut feelings." 
These types of codes are always present in one way or another, whether in oral or written communication, but there are certain other accompanying codes which are optional and to which the verbal message must adjust in varying ways, e.g. the action in a drama, the music of a song, and the multiple visual and auditory features of a multimedia essay. These optional codes often become the dominant factors in a translation, especially when lip synchronization is required in television films.

The problem of multiple codes and their relation to the social setting of communication have been helpfully treated by a number of persons, e.g. Eco (1976), Krampen (1979), Merrell (1979), and Robinson (1985). The beginning of a sociosemiotic approach to translating has been undertaken by de Waard and Nida (1986) and by Toury (1980), but a good deal more must be done to understand the precise manner in which the language code relates to other behavioral codess.

In the first place, language must be viewed not as a cognitive construct, but as a shared set of habits using the voice to communicate. This set of habits has developed within society, is transmitted by society, and is learned within a social setting. This implies a clear shift away from abstract and reductionist approaches to language and toward the sociolinguistic contexts of performance in both encoding and decoding messages communicated by multiple codes. This also means that in both encoding and decoding there is a dialogic engagement between source and receptors, both in anticipatory feedback (anticipating how receptors will react) and in actual feedback through verbal and nonverbal codes.

In the second place, language must also be viewed as potentially and actually idiosyncratic and sociosyncratic, in the sense that people may create new types of expressions, may construct new literary forms, and may attach new significance to older forms of expression. Discourse, in fact, becomes as much a matter of fashion as any other element of communication, and outstanding communicators can set new standards and initiate new trends.

The advantages of a sociosemiotic approach to translating are to be found in (1) employing a realistic epistemology which can speak relevantly about the real world of everyday experience, since its basis is a triadic relation between sign, referent, and interpretant (the process of interpretation based on the system of signs and on the 
dialogic function of society), (2) being at the cutting edge of verbal creativity, rather than being bound by reductionist requirements which depend on ideal speaker-hearers, who never exist, (3) recognizing the plasticity of language, the fuzzy boundaries of usage, and the ultimate indeterminacy of meaning, which makes language such a frustrating and subtly elegant vehicle for dialogue, and (4) being essentially interdisciplinary in view of the multiplicity of codes. The full implications of sociosemiotic theories and their relation to translation are only now emerging, but they have the potential for developing highly significant insights and numerous practical procedures for more meaningful and acceptable results.

\section{References}

ANTAL, Laszlo (1963). "Interpretation and Transformation." Linguistics, 2, pp. 16-25.

ARISTOPHANES (1924). Aristophanes, with English translation by Benjamin Bickley Rogers, Volume 1. Cambridge, MA, Harvard University Press. (3 vols.)

BELL, Roger T. (1987). "Translation Theory: Where are we going?" Meta, 32, pp. 403-415.

BROWER, Reuben A. (1959). On Translation. Cambridge, MA, Harvard University Press, 296 p.

CARY, E., and R.E. Jumpelt, eds. (1963). Quality in Translation. New York, Macmillan, 544 p.

CASSIRER, Ernst (1953). The Philosophy of Symbolic Forms. Vol. 1: Language. New Haven, Yale University Press. (3 vols.)

CATFORD, J.C. (1965). A Linguistic Theory of Translation. London, Oxford University Press, 103 p.

CHOMSKY, Noam (1965). Aspects of the Theory of Syntax. Cambridge, MA, M.I.T. Press, 251 p. 
(1972). Studies on Semantics in Generative Grammar. The Hague, Mouton, 207 p.

COWLEY, Abraham (1656). Poems. Preface to "Pindarique Odes". London, Humphrey Moseley. (Various pagings.)

DOLET, Étienne (1540). "La manière de bien traduire d'une langue en autre" in E. Cary (1955). "Étienne Dolet", Babel, 1, pp. 17-20.

DRYDEN, John (1680). Ovid's Epistles. London, Jacob Tonson, 280 p.

ECO, Umberto (1976). A Theory of Semiotics. Bloomington, IN, Indiana University Press, $354 \mathrm{p}$.

DE WAARD, Jan, and Eugene A. Nida (1986). From One Language to Another. Nashville, TN, Thomas Nelson, 224 p.

FELSTINER, John (1980). Translating Neruda. Stanford, CA, Stanford University Press, $284 \mathrm{p}$.

FRAWLEY, William, ed. (1984). Translation: Literary, Linguistic, and Philosophical Perspectives. Newark, Delaware, University of Delaware Press, $218 \mathrm{p}$.

GRICE, H.P. (1968). "Utterer's meaning, sentence-meaning, and wordmeaning", Foundations of Language, 4, pp. 225-292.

GRIMES, Joseph E. (1972). The Thread of Discourse. Ithaca, NY, Department of Modern Languages and Linguistics, Cornell University, $374 \mathrm{p}$.

GUMPERZ, John Joseph (1982). Language and Social Identity. Cambridge-New York, Cambridge University Press, 272 p.

GÜTTINGER, Fritz (1963). Zielsprache. Zurich, Manesse Verlag, 234 p.

HARRIS, Brian, and Sherwood Bianca (1978). "Translating as an innate skill", Language Interpretation and Communication, ed. by David Gerver and H. Wallace Sinaiko, pp. 155-170. New York, Plenim Press. 
HYMES, Dell (1974). Foundations in Sociolinguistics: An Ethnographic Approach. Philadelphia, University of Pennsylvania Press, 245 p.

JAKOBSON, Roman (1960). "Linguistics and poetics", Style in Language, ed. by Thomas A. Sebeok, pp. 350-377. Cambridge, MA, Technology Press.

KRAMPEN, Martin (1979). "Profusion of Signs without Confusion", Ars Semeiotica, 2, pp. 327-359.

LABOV, William (1972). Sociolinguistic Patterns. Philadelphia, University of Pennsylvania Press, 344 p.

LADMIRAL, Jean-René, ed. (1972). "La traduction", Langages, 28; Paris, Didier-Larousse, $120 \mathrm{p}$.

LAMBERT, W.E. (1978). "Psychological approaches to bilingualism, translation and interpretation", Language Interpretation and Communication, ed. by David Gerver and H. Wallace Sinaiko, pp. 131-143, New York, Plenum Press.

LANGER, Suzanne K. (1951). Philosophy in a New Key. New York, New American Library, $256 \mathrm{p}$.

LARSON, Mildred L. (1984). Meaning-based Translation: A Guide to Cross-Language Equivalence. Lanham, MD, University Press of America, $537 \mathrm{p}$.

LEECH, Geoffrey N. (1970). Towards a Semantic Description of English. Bloomington, IN, Indiana University Press, 277 p.

LUTHER, Martin (1530). "Ein Sendbrief von Dolmetschen", Werke.

MALONE, Joseph L. (1988). The Science of Linguistics in the Art of Translation. Albany, NY, State University of New York Press, $241 \mathrm{p}$.

MERRELL, Floyd (1979). "Some signs that preceded their times: Or, Are we really ready for Peirce?" Ars Semeiotica, 2, pp. 149172. 
MORAVSCIK, J.M.E. (1972). Review of Towards a Semantic Description of English by Geoffrey N. Leech (Bloomington, Indiana University Press, 1970), Language, 48, pp. 445-454.

MOUNIN, Georges (1963). Les Problemes théoriques de la traduction. Paris, Gallimard, 296 p.

NIDA, Eugene A. (1964). Toward a Science of Translating. Leiden, E.J. Brill, 331 p.

NIDA, Eugene A., and Charles R. Taber (1969). The Theory and Practice of Translation. Leiden, E.J. Brill, $218 \mathrm{p}$.

PAZ, Octavio (1971). Traducción, literatura y literalidad. Barcelona, Ediciones Tusquets, $78 \mathrm{p}$.

POPE, Alexander (1715). Preface to his translation of Homer's Iliad. London, Donaldson, 1769; New York, D. Appleton, 1901.

QUINE, Willard V.O. (1953). "The problem of meaning in linguistics", in his From a Logical Point of View, pp. 47-64. Cambridge, Harvard University Press.

(1959). "Meaning and translation", see Brower (1959), pp. 148172.

REISS, Katharina (1971). Möglichkeiten und Grenzen der Übersetzungskritik. München, Max Hueber Verlag, 124 p.

RICHARDS, I.A. (1953). "Toward a Theory of Translating", Studies in Chinese Thought, ed. by Arthur F. Wright, Chicago, University of Chicago Press, pp. 247-262.

RICCEUR, Paul (1969). Le Conflit des interprétations: essais d' herméneutique. Paris, Éditions du Seuil, 505 p.

ROBINSON, Douglas (1985) "C.S. Peirce and dialogic pragmatism", Kodikas/Code, 8, pp. 179-194.

SOMERS, Harold, Hideki Hirakawa, Seiji Miike, and Shinya Amano (1988). "The treatment of complex English nominalizations in machine translation", Computers and Translation, 3, pp. 321. 
STEINER, George (1975). After Babel: Aspects of Language and Translation. London, Oxford University Press, 507 p.

TATILON, Claude (1986). Traduire: Pour une Pédagogie de la Traduction. Toronto, Éditions du Gref.

TOURY, Gideon (1980). In Search of a Theory of Translation. Tel Aviv, The Porter Institute for Poetics and Semiotics, Tel Aviv University, 159 p.

TRAUGOTT, Elizabeth Closs, and Mary Louise Pratt (1980). Linguistics for Students of Literature. New York-London, Harcourt Brace Jovanovich, 444 p.

VÁZQUEZ AYORA, Gerado (1977). Introducción a la Traductología. Washington, D.C., Georgetown University Press, 471 p.

VINAY, J.-P. and J. Darbelnet (1958). Stylistique comparée du français et de l'anglais: Méthode de traduction. Paris, Didier; Montréal, Beauchemin, 331 p.

WELLS, Rulon S. (1954). "Meaning and Use", Word, 10, pp. 235250.

WILSS, Wolfram (1988). Kognition und Übersetzen: Zu Theorie und Praxis der menschlichen und der maschinellen Übersetzung. Tübingen, Max Niemeyer Verlag, 306 p.

WITTGENSTEIN, L. (1953). Philosophical Investigations. New York, Macmillan; Oxford, Blackwell, 232/232 p. [facing pages numbered the same] 